\title{
Legal Position Of A Person Who Is Not Attended (Afwezigheid) According To The Kuhperdata (Case Study At The Career Of Health Of Medan)
}

\section{Jessica Vania Theresa Samosir}

Sumatera University Faculty Of Law.E-mail: jessicasamosir@gmail.com

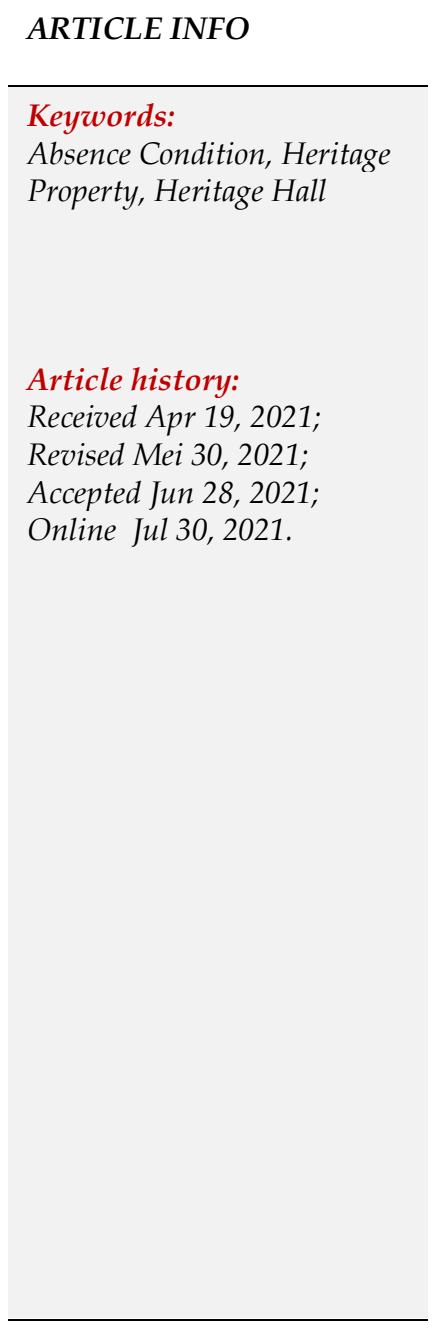

\begin{abstract}
The development of technology and information does not guarantee that someone's whereabouts are unknown to others. Over time, it turns out that there is still a state of absence (afwezigheid), where a person's whereabouts are not known. With the condition of a person's whereabouts is not known by the family or community where he has committed a legal act, a problem will arise regarding the legal status of the person, this will relate to the interests of other people, namely the family left behind and will also intersect with various legal aspects, including the person's inheritance. The legal status of the person declared in a state of absence (afwezigheid), Based on this background, the issues raised are how the procedures for implementing and managing assets from an absence state (afwezigheid) by the Medan Heritage Property Center are held, what is the responsibility of the Medan Heritage Property Office in managing absenteeism fees (afwezigheid) and what is the role of the Medan Heritage Property Center in implementing and management of inheritance based on Court Decision Number 123/Pdt.P/2005/PN.TTD. The research method used in this study is descriptive analytical research, because it aims to describe the real situation, then the data obtained are analyzed qualitatively. Data were obtained through library research, namely collecting theoretical materials from the literature such as primary legal materials, secondary legal materials, and tertiary legal materials. The process of managing the assets of people who are not present (afwezigheid) is carried out starting from the recording stage to the stage of managing boedel in an absent state (afwezigheid). The responsibility of the Medan Heritage Treasurer in managing boedel absences (afwezigheid) is carried out until a period of 30 years and then becomes the property of the State, the role of the Medan Heritage Treasures in managing boedel absences (afwezigheid) based on Court Decision Number 123/Pdt.P/2005 /PN.TTD has been in accordance with the duties and functions of the Heritage Office.
\end{abstract}

This is an open access article under the CC BY-NC license.

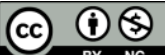

\section{Introduction}

In the era of advances in science and technology at this time which is increasing, especially in the field of information and communication, it can be felt by individuals, either individually or as family members or as members of the community. If a person becomes a member of a family, then with advances in information technology and communication it will be easier to find out the whereabouts of a person with his family or with the person concerned when traveling far and being in another area far from the family. Advances in information and 
technology will facilitate all aspects of human life, including the legal aspect, where humans or individuals are legal subjects who hold rights and obligations in carrying out legal actions.

However, the reality that exists in Indonesian society at this time, the progress of information and technology is still not a legal certainty to know someone's whereabouts. Over time, it turns out that there is still a state of absence (afwezigheid), where a person's whereabouts are not known. With the condition of a person's whereabouts is not known by the family or the community where he has committed a legal act, a problem will arise regarding the legal status of the person, this will relate to the interests of other people, namely the family left behind and will also intersect with various legal aspects between other property left by that person.

Problems arise when there are cases of missing persons or whose whereabouts are unknown will create legal uncertainty in matters relating to inheritance and legal actions against their own families. Regarding inheritance if a person is lost or his whereabouts are not known and does not leave power of attorney or does not appoint a proxy in advance so that it will create a situation that makes it difficult for other people or the family he left behind to take care of and carry out a legal action, especially those closely related to assets owned by him. owned by the person who is declared in a state of absence (afwezigheid).

In civil law, it is known as a state of absence (afwezigheid), which is a condition in which a person does not occupy or reside in his place of residence for certain reasons and his whereabouts are not clearly known. According to the Civil Code, the state of being absent (afwezigheid) is divided into three phases, namely the preparatory phase or temporary action (voorlopige voozieningen), the statement phase that someone who is absent may have died or has died (vermoedelijk overleden) and the phase of definitive inheritance (definitieve erfopvolging). ). In every phase, the person who is not in that place originally still has the right and authority to act, if he reappears then all his rights and obligations return to him with certain conditions or restrictions. 1 The condition of absence (afwezigheid) can cause a problem, namely the alleged death, this allegation arises when the search effort has been carried out with all efforts, with the intercession of other people, with the help of state officials, with the help of technology and information facilities, but the whereabouts of the person is not known. concerned. Regarding a person who is declared in a state of absence (afwezigheid), if he does not give a message to other people or a power of attorney to the heirs in terms of managing the assets they have, civil law regulates the grace period for the length of time a person does not appear on the spot. with the help of technology and information facilities but the whereabouts of the person concerned is not known. Regarding a person who is declared in a state of absence (afwezigheid), if he does not give a message to other people or a power of attorney to the heirs in terms of managing the assets he has, civil law regulates the grace period for the length of time a person does not appear on the spot. with the help of technology and information facilities but the whereabouts of the person concerned is not known. Regarding a person who is declared in a state of absence (afwezigheid), if he does not give a message to other people or a power of attorney to the heirs in terms of managing the assets they have, civil law regulates the grace period for the length of time a person does not appear on the spot.

The legal status of the person who is declared absent (afwezigheid), must first be stated in a decision from the District Court which declares that the person is not present (afwezigheid). A deed regarding a person's legal status is very important in terms of recording carried out by a civil registry institution which aims to provide complete information and therefore also to provide legal certainty regarding events related to a person's legal position. The recording is not only useful for the person who recorded it but also for other interested parties. The status of a person who is declared in a state of absence (afwezigheid) is very closely related to the agency or institution which according to the law is entrusted to manage or administer the rights to a person's assets stated in an absence state (afwezigheid). The descriptions of the legal 
institution in charge of managing the rights to assets belonging to someone who is declared in a state of absence (afwezigheid) is the Balai Harta Peninggalan (BHP).

The state of absence (afwezigheid) according to the existing legal system is applied to human legal subjects, must be stated and can be proven its existence or existence in a District Court Decision (Article 463 of the Civil Code). In determining the absence of attendance, a local Heritage Treasurer may be appointed at the same time who will be tasked with managing and representing and defending all the interests of someone who is declared in a state of absence (afwezigheid), but without reducing the authority of the judge to appoint someone or more from the family or by the name of the a person who is declared in a state of absence (afwezigheid) or to his wife or husband for the purposes of managing inheritance (Article 463 paragraph (3) of the Civil Code).

Balai Harta Peninggalan as a government agency within the Ministry of Law and Human Rights of the Republic of Indonesia, one of its duties is to represent the interests of those who are declared absent (afwezigheid) and have a very important role in carrying out the management and management of assets whose owners are declared absent. (afwezigheid). The Balai Harta Peninggalan is an institution which based on the law is given the task and authority to manage and represent all interests of legal subjects who are declared in a state of absence (afwezigheid) in accordance with Article 463 of the Civil Code3 and other regulations relating to management.

\section{Method}

Research has meaning and purpose as a search effort and is not just a careful observation of an object that is visible to the naked eye.5 In this study the approach method used was a normative juridical research method. The normative juridical research method is an approach to the relationship between juridical factors (positive law) and normative factors (legal principles).

After all the data obtained are collected, the next step that must be done is data analysis. At this stage the data collected will be processed and utilized in such a way that it can be used to answer in such a way that it can be used to answer problems.

Analysis of the data used in this study is normative qualitative data analysis, namely data obtained after being systematically arranged, then analyzed qualitatively normatively in the form of descriptions, so that conclusions can be drawn to achieve clarity on the problems to be studied. The results of the literature research will be used to analyze the data, then the normative qualitative data to answer the problems in this thesis.

\section{Analysis And Results}

\subsection{Legal Position Of People Who Are Not Available (Afwezigheid) According To The Data Certificate}

\section{a. Overview of Medan Heritage Hall}

The Medan Heritage Center is located on Jalan Electrical Number 10 Medan. The Balai Harta Peninggalan is a technical implementing unit for government agencies which is structurally under the Directorate of Civil Affairs, the Directorate General of General Legal Administration, the Ministry of Law and Human Rights of the Republic of Indonesia. At the beginning of its establishment, there were 5 (five) Heritage Halls in Indonesia, namely: in Jakarta, Semarang, Surabaya, Medan and Ujung Pandang, with representatives appointed by the Minister of Justice in accordance with Article 40 of the Instruction for Heritage Halls in Indonesia Staatblad 
1872 Number 166 and a member of the delegation from the Medan Heritage Center based in Padang.

b. Procedure for the Implementation and Management of Assets from Absence (Afwezigheid) by the Medan Heritage Center

In principle, those who can apply for absenteeism (afwezigheid) are only human legal subjects, with the understanding that human legal subjects who can be declared absent (afwezigheid) are human legal subjects who according to law are capable of acting to carry out legal actions and who leave their domicile. without setting all the interests of his legacy.

The law itself does not provide a limit on whether to leave one's place of residence voluntarily or out of necessity. Legal entities according to the Civil Code system cannot be declared absent, because in carrying out their daily activities and activities they are always represented by their management, and also the legal entity cannot leave the domicile that has been determined by its founders in its articles of association. In addition, it is the management itself who can change the domicile of the legal entity by making necessary changes in the deed.

Based on the results of interviews conducted with Mr. Syuhada as a Legal Technical Member of the Medan Treasurer's Office, he explained that in practice, in general, the conditions for advancing a request for absence can be stated as follows:

1) A person can prove that he controls the property of another person, for example controlling 1 (one) door of the house building and its yard, while the whereabouts of the owner of the building and yard are unknown.

2) A person leaves his residence without authorizing another person to represent him, and does not appoint or assign to another person to take care of his interests.

3) Representing and managing the interests of people who are not present, not only covering their assets, but also for their personal interests.

4) It is the intention of the occupant to own a house and yard belonging to a person who is no longer known where it is located through legal channels permitted by law.

5) Can show documents of evidence, that a person has left his place of residence (domicile), and it is no longer known where he is. These letters are letters issued by authorized agencies, for example, village heads, sub-district heads and others.

6) Witnesses can be presented at the trial of the petition who know that it is true that a person has left his place of residence (his domicile).

7) There is a District Court stipulation to determine whether it is true that a person has left his place of residence (domicile).

If these elements are fulfilled, then a person can be declared in a state of absence (afwezigheid), so it is necessary to appoint a representative who will carry out the rights and carry out the relevant obligations.

\section{c. Accountability of the Medan Heritage Office in the Management of Boedel Absence (Afwezigheid)}

The Balai Harta Peninggalan as the administrator (bewindvoerder) and the manager of afwezigheid assets, each year briefly provides a calculation of accountability to the Prosecutor's Office and the District Court who appoint and stipulate as administrators of the assets of people who are declared absent (afwezigheid), and show them to the public. Court of all documents relating to the management carried out by the Heritage Hall, for the calculation and accountability, the Prosecutor's Office may submit proposals to the District Court for the benefit of the subject who is declared absent (afwezigheid).

1) The Accountability of the Heritage Office for the proceeds of the sale of the assets of the person declared in the absence. Based on an interview with Mr. Syuhada as a Legal Technician Member of the Medan Treasures Hall, he stated that the proceeds from the sale of boedel afwezigheid in the form of money will be stored and managed by the Heritage 
Hall for 30 (thirty) years or a third of a century and the Heritage Hall will keep the money at a Government Bank in the form of a deposit, if within 30 (thirty) years or a third of a century if no party submits or claims to be declared afwezigheid, then the Heritage Hall based on Staatblad 1836 Number 56 juncto Staatblad 1850 Number 3 is obliged to submit closing calculation to the State Audit Board and if the calculation is approved,Furthermore, the Balai Harta Peninggalan submits an application to the local District Court so that the boedel afwezigheid is determined to be the property of the State, by first taking into account:

2) Profit in the form of interest during the management with a percentage according to the interest rate determined by the Minister of Justice (now the Minister of Law and Human Rights of the Republic of Indonesia) every year.

3) Cost of advertising and State News.

4) Continuous wages, estimated wages and others, will be transferred to the State.

From the description above, it can be concluded that as long as the assets of the absentee (afwezigheid) have not been handed over to the rightful person or to the State, the Heritage Hall only has temporary control. In carrying out its duties as a manager (bewindvoerder) who has a legal obligation to defend and represent the interests of the absentee, Balai Harta Peninggalan seeks to minimize all things that allow the occurrence of conditions that can cause harm to the assets of the absent person, both in carrying out its management and management. by carrying out various steps and efforts as regulated in the provisions of the legislation, so in order to avoid losses to the boedel in the absence (afwezigheid) and to prevent the boedel from being declared a destroyed and neglected building, usually the Heritage Hall sells the boedel in the absence (afwezigheid) after going through the procedures and conditions set by the applicable regulations. and wages for boedel management according to the law that governs it. This is done with a view to simplifying the management and management. Afwezigheid assets in the form of movable goods are generally rarely found even though there are relatively small amounts, usually assets in the form of cash, which is the result of the sale of boedel absenteeism (afwezigheid) in the form of land and house buildings belonging to the absentee which are developed and stored by the Balai Harta Peninggalan by depositing them in a Governmentowned Bank. The Balai Harta Peninggalan manages the boedel in a state of absence (afwezigheid) which has been in the form of money for $1 / 3$ of a century, and after that time the Balai Harta Peninggalan must apply for a Court Decision to declare the balance of the boedel as property of the State.

d. The Role of the Heritage Office in the Implementation and Management of Inherited Assets based on the Decision of the Tebing Tinggi District Court of Deli Number 123/Pdt.P/2005/PN.TTD

After describing the procedures and stages of managing the assets of people who are declared absent (afwezigheid), this discussion will describe the completion of the management of the assets of people who are declared absent (afwezigheid) regulated by civil law and other regulations.

Guidelines and legal provisions regarding absenteeism (afwezigheid) and the management of assets are regulated in the Civil Code and other Decrees of the Minister of Justice. To be able to describe the legal guidelines and provisions determined by the Civil Code in discussing and resolving problems, the opinions expressed by J. Satrio are as follows: "Before it is necessary to know, that there are 2 (two) articles in the law that we can use as a benchmark to discuss what is meant by a state of absence, namely Article 463 and Article 467 of the Civil Code, and as it will later turn out, both contain elements -more or less the same elements".

The role of the Balai Harta Peninggalan in the implementation and management of inheritance based on the Decision of the Tebing Tinggi District Court of Deli Number 123/Pdt.P/2005/PN.TTD can be briefly identified through: 
1) Position Case:

b) ST. Mansyur alias STM and Adamsori alias AS are a husband and wife whose marriage is blessed with 6 (six) children.

c) Since 1954 STM and AS have inhabited and occupied a house located at Veterans number 3 RT/RW 003, Tebing Tinggi Village, Padang Hilir Subdistrict, Tebing Tinggi Municipality, with a building area of 179 M2, with a land area of 116 M2 in accordance with a certificate from the Office of Public Affairs. Medan Branch Housing in Tebing Tinggi dated 30 September 1954 and a certificate from the Deli Serdang Regency Housing Affairs Office/Tebing Tinggi Municipality dated 6 November 1978 Number 208/II/KUP/78.

d) STM died on March 13, 1960 and AS died on January 12, 1977.

e) At the time of his death, STM bequeathed the house to Hazni alias HZ who was the eldest child of STM in accordance with the inheritance statement which was known and ratified by the Head The old Tebing Tinggi sub-district and the Padang Hilir subdistrict head of the Tebing Tinggi municipality were corroborated by witnesses.

f) After their parents died, the eldest child named HZ who received approval from the other heirs to apply for a Housing Permit (SIP) to be renewed to the Tebing Tinggi Municipal Housing Affairs Office, and the Housing Permit issued on behalf of HZ.

g) However, for now the oldest heir, namely HZ, has died along with 2 (two) other heirs, and until now the only remaining heirs are 3 (three) people.

h) Until now, the management and extension of the Housing Permit (SIP) have been continued by the surviving heirs, namely Murni alias MR, Syamsul Bahri alias SB and Yusminar Azhari YZ who are the applicants.

i) The heirs intend to take care of the Land Registration Certificate (SKPTD) issued by the National Land Office of Tebing Tinggi Municipality dated October 8, 2002 Number 630-02/10/2002, land and buildings located on Jalan Veteran number3 RT/RW 003 Tebing Tinggi Subdistrict, Padang Hilir Subdistrict, Tebing Tinggi Municipality covering an area of $116 \mathrm{M} 2$, the certificate cannot be issued yet because the title is incomplete.

j) The surviving heirs intend to apply for a certificate of land located at Veteran number 3 RT/RW 003 Kelurahan Tebing Tinggi, Padang Hilir District, Tebing Tinggi Municipality, however, the National Land Office has not been able to issue a certificate of ownership of the land because there has been no written release of rights from the first party to STM as the occupant of the house.

k) The applicant is an STM heir who is still alive and continues to pay Land and Building Tax (PBB) until the tax payable in 2004/2005.

1) The heirs who are still alive until now have tried to find the whereabouts of the owner of the land and buildings in order to be able to carry out the release of rights by buying and selling and compensation to the owner, but the whereabouts of the owner and heirs of the house are not known whether he is still alive or not.

m) Therefore, the applicants who are the heirs have contacted the Medan Heritage Office and submitted an application so that the ownership of the house/land becomes theirs in accordance with the application letter dated December 5, 2005.

Medan Heritage Office, represented by the Chairman of the Medan Heritage Office to sell the boedel in the absence (afwezigheid), the Medan Heritage Office is required to notify the report on the management and settlement of the absentee boedel (afwezigheid) in the form of land and houses located on Jalan Veteran number 3 RT/RW 003 Tebing Tinggi Village, Padang Hilir District, Tebing Tinggi Municipality to the Directorate General of General Legal Administration, Ministry of Law and Human Rights of the Republic of Indonesia. After the report is made, the proceeds from the sale of boedel in an absent state (afwezigheid) must be deposited in a government bank and managed by the Medan Heritage Center for up to $1 / 3$ century (30 years). 
From the explanation above, it can be concluded that, the flow of the process of managing and settling assets declared in an absent state (afwezigheid) in the form of land and buildings located on Jalan Veteran number 3 RT/RW 003 Kelurahan Tebing Tinggi, Padang Hilir District, Tebing Tinggi Municipality based on the determination Court Number 123/Pdt.P/2005/PN.TTD dated December 26, 2005, starting from the registration process, the determination of the District Court, and the management of the assets of people who are declared absent (afwezigheid). the settlement of the assets of people who are declared absent (afwezigheid) and the management of the assets of people who are declared absent (afwezigheid) are in accordance with applicable procedures.

\section{Conclusion}

Procedure for the Implementation and Management of Assets from an Absence (Afwezigheid) by the Medan Heritage Office. The procedure for managing the assets of people who are declared in an absent state (afwezigheid) by the Medan Heritage Property Center starts from the registration stage which is an application for property management in an absence (afwezigheid) to Balai Harta Peninggalan, this summons stage is carried out after the Balai Harta Peninggalan receives a Court Decision then the Balai Harta Peninggalan makes summons at least 3 (three) times in a row, the recording stage is the Balai Harta Peninggalan makes official reports, maintains and keeps records of assets wealth in detail then announced in the State Gazette,the reporting stage, which is the Balai Harta Peninggalan submitting written notification regarding the determination of absence (afwezigheid) to the Supreme Audit Agency of North Sumatra Province and the Tebing Tinggi District Attorney's Office, the stage of the lease agreement in this stage the lease agreement occurs where the person requesting the stipulation state of absence (afwezigheid) paying rent to Balai Harta Peninggalan, stage of permission to sell people's assets in an absent state (afwezigheid) at this stage after obtaining a sale permit determination from the Ministry of Law and Human Rights, Balai Harta Peninggalan ordered an appraisal team from the Court local government and the Heritage Office to make an estimated price according to the market value,and the last stage is the stage of managing boedel absences (afwezigheid). In this stage, the Balai Harta Peninggalan must manage and submit closing calculations to the Supreme Audit Agency after being managed for more than $1 / 3$ century (30 years).

The Accountability of the Medan Heritage Treasurer in the Management of the Absence of Boedel (Afwezigheid) In carrying out its duties as a bewindvoerder who has a legal obligation to defend and represent the interests of the absentee, the Medan Heritage Office seeks to minimize all things that allow the occurrence of situations that can occur. cause harm to the assets of the absent person (afwezigheid) both in carrying out management and management by carrying out various steps and efforts as regulated in the provisions of the Act. Medan Heritage Center as the administrator (bewindvoerder) and the manager of the assets of people who are declared absent (afwezigheid).

Money from the sale of assets of people who are declared in a state of absence (boedel afwezigheid) while in the management of the Balai Harta Peninggalan is kept and/or deposited in Government-owned banks registered in the name of the Balai Harta Peninggalan cash during the processing process for up to 30 (thirty) years. ) year.

The Medan Heritage Office manages the boedel in the absence of money (afwezigheid) which has been in the form of money for $1 / 3$ of a century, and after the time comes, the Medan Heritage Office is obliged to apply for a Court Decision to declare the balance of the boedel to belong to the State.

The Balai Harta Peninggalan represents a person who is declared absent (afwezigheid) if there is a third party who claims that he or she owns the assets of the person declared in an absent 
state (afwezigheid) and processes it in accordance with the applicable procedures. If in the stage of managing the results of boedel afwezigheid, the person who is declared in a state of absence (afwezigheid) comes back, the responsibility of the Balai Harta Peninggalan in this case must return his rights in accordance with the applicable procedures and regulations.

The Role of the Heritage Office in the Implementation and Management of Inherited Assets based on Court Decision Number 123/Pdt.P/2005/PN.TTD In the process of managing and settling assets declared in a state of absence (afwezigheid) in the form of land and buildings located on Jalan Veteran number 3 RT/RW 003, Tebing Tinggi Village, Padang Hilir District, Tebing Tinggi Municipality, the Medan Heritage Office has carried out in accordance with its functions and duties as a party representing people who are not present (afwezigheid) to take care of and represent all the needs of people who are stated in a state of absence (afwezigheid).

The Medan Heritage Center has carried out in accordance with the procedures determined by the prevailing laws and regulations starting from the registration stage to the sale of the property of people who are declared absent (afwezigheid) in accordance with the instructions issued through the Decision of the Tebing Tinggi District Court of Deli Number 123/Pdt.P/2005/PN.TTD.

\section{References}

Afandi, Ali. 2004. Inheritance Law, Family Law, Law of Evidence. Rineka Cipta. Jakarta.

Ali, Chidir. 1991. Legal Entities. Alumni. Bandung.

Ali, Zainuddin. 2009. Legal Research Methods. Graphic Ray. Jakarta. Baros, Wan Sadjaruddin. 1985. Essence of Civil Law Concerning the Law of Persons.

USU Faculty of Law. Medan.

Daliyo, JB 2001. Introduction to Indonesian Law Student Handbook. Prenhallindo. Jakarta.

Kamello, Tan et al. 2011. Civil Law: Person and Family Law. USU Press. Medan.

Komariah, 2010. Revised Edition of Civil Law. University of Muhammadiyah Malang.

Mahdi, Sri Soesilowati et al. 2005. Civil Law An Introduction. Gitama Jaya. Jakarta.

Meliala, Djaja S. 2007. Development of Civil Law Regarding Persons and Family Law. Aulia nuance. Bandung.

Muhammad, Abdulkadir. 2011. Indonesian Civil Law. Image of Aditya Bakti. Bandung. 2000. Indonesian Civil Law. Aditya's Image devotion. Bandung.

Satrio, J. 1999. Personal Law Part I Natural Person. Citra Aditya, Bandung.

1993. Description of the Definition of Daad Van Beheer and Daad Van Beschikking. Image of Aditya Bakti. Bandung.

Simanjuntak, PNH 2009. Principles of Civil Law Revised Edition. Bridge. Jakarta.

Sjarif, Surini Ahlan. 1986. Digest Law of Inheritance According to Burgerlijk Wetboek. Indonesian Ghalia. Jakarta.

Soemitro, Roni Hanitijo. 1998. Legal Writing Methodology and Jurimetry. Indonesian Ghalia. Jakarta. 
.1990. Legal Research Methodology. Indonesian Gall. Jakarta. Soekanto, Soerjono. 1986. Introduction to Legal Research. UI Press. Jakarta.

Soekanto, Soerjono et al. 1985. Normative Legal Research. King Grafindo Persada. Jakarta.

Subekti, R. 2001. Principles of Civil Law. Intertime. Jakarta.

Subekti, R et al. 2004. The Civil Code. Pradnya Paramita. Jakarta.

Sudarsono. 1991. National Family Law. Rineka Cipta prints I. Jakarta.

sunggono, Bambang. 2003. Methodology Study Law (SomethingIntroduction). King Grafindo Persada. Jakarta.

Suhardana, FX 1992. Civil Law I Student Handbook. Prenhallindo. Jakarta.

Syahrani, Riduan. 2004. Ins and outs and Principles of Civil Law. Alumni. Bandung.

Usman, Rachmadi. 2005. Aspects Law Individual and Family in Indonesia. Graphic Ray. Jakarta.

Vollmar, HFA 1996. Introduction to the Study of Civil Law. King Grafindo Persada. Jakarta.

Waluyo, Bambang. 1996. Legal Research in Practice. Graphic Ray. Jakarta.

Law Number 12 of 2006 concerning Citizenship of the Republic of Indonesia.

Law Number 37 of 2004 concerning Bankruptcy and Suspension of Debt Payment Obligations.

Law Number 23 of 2002 concerning Child Protection.

Law Number 1 of 1958 concerning the Elimination of Particle Lands.

Government Regulation Number 2 of 1945 concerning Government Agencies and Regulations

Decree of the Minister of Justice of the Republic of Indonesia Number M.01-KP.09.05 of 1991 concerning the Determination of Position Descriptions within the Ministry of Justice.

Decree of the Minister of Justice of the Republic of Indonesia Number M.06.PR.07.01 of 1987 dated June 29, 1987 concerning the Elimination of Representatives of the Heritage Center in Tanjung Pinang, Padang, Palembang, Bogor, Bandung, Tasikmalaya, Cirebon, Pekalongan, Surakarta and Malang.

Decree of the Minister of Justice of the Republic of Indonesia Number: M.01.PR.07.01-80 of 1980 concerning the Organization and Work Procedure of the Heritage Center.

Decree of the Minister of Justice of the Republic of Indonesia of the Republic of Indonesia, Number 1 of 1958 concerning the Elimination of Particle Lands.

Decree of the Minister of Justice and Security of the Republic of Indonesia Number M.47-PR.09.03 of 1987 concerning the Committee for Estimating and Determining Prices for Assets whose owners are declared absent (afwezigheid) and unmanaged heritage assets (onbeheerde nalatenschap) in the form of houses or land.

Stipulation of the Minister of Justice on September 20, 1955 Number 2270/DHP4.

Circular Letter of the Minister of Justice of the Republic of Indonesia Number M.01.HT.05.10.Year 1990 concerning Instructions for Submitting Applications for Principles and Permits for the Implementation of the Sale of Boedel Afwezig and Onbeheerde Nalatenschap which are under the supervision and management of the Balai Harta Peninggalan. 
Syuhada, 1991, The Process for the Settlement of Afwezig's Case of the Owner of the Bank Of China Building by the Medan Heritage Center, (Unpublished Thesis, Faculty of Law, University of Medan Area).

Sa'roni, 2006, Responsibilities of Balai Harta Peninggalan As Curator of Bankrupt Assets After the Enactment of Law Number 37 Year 2004 concerning Bankruptcy, (Unpublished Postgraduate Thesis, Notary Masters Study Program, Diponegoro University)

Materials for the Training of Technical Personnel of the Heritage Center, 2006, Jakarta. Sjafruddin, Main Duties and Functions of the Heritage Hall In The scope of the Ministry of Law and Human Rights is linked with Rules Executor, (Paper no published, Department of Law and Human Rights).

www.wikipedia.org//Balai_Harta_Peninggalan downloaded on Tuesday, December 18, 2012 at 17.00 WIB.

http:/ / bhpjakarta.info/index.php?option=com, downloaded Saturday 09 February 2013 at 20.00 WIB. , downloaded on Monday, December 16, 2012 at 07.30 WIB.

http:/ / bhpsby.blogspot.com/2008/06/uraian-tas-pokok-balai-harta.htmldownloadedMonday, December 10, 2012 at 21:47 WIB.

http:/ / bhpsby.blogspot.com/2008/06/uraian-tas-pokok-balai-harta.htmldownloadedMonday, December 10,2012 at 21:47 WIB.

http://bhpsby.kemenkumham.go.id/profile/sejarah-bhp, downloaded Monday, December 10, 2012 at 21:47 WIB 